\title{
Equilibrium
}

Quarterly Journal of Economics and Economic Policy

VOLUME 8 ISSUE 3, 2013

ISSN 1689-765X, (Online) ISSN 2353-3293

http://www.equilibrium.umk.pl/

Wolszczak-Derlacz J. (2013), The Impact of Gender Wage Gap on Sectoral Economic Growth - Crosscountry Approach, "Equilibrium. Quarterly Journal of Economics and Economic Policy", Volume 8, Issue 3, pp. 103-122, DOI: http://dx.doi.org/10.12775/EQUIL.2013.022

\section{The Impact of Gender Wage Gap on Sectoral Economic Growth - Cross-country Approach ${ }^{* *}$}

JEL Classification: $J 16, J 31, F 43$

Keywords: gender wage gap, economic growth, manufacturing sectors

\begin{abstract}
We propose an empirical analysis of testing the relationship between gender wage gap and economic growth. The study takes into account 12 manufacturing sectors in 18 OECD countries for the period between 1970 and 2005. We use industrial statistics (EU KLEMS, 2008) on female and male wages that distinguish between wages paid to different groups of workers classified according to skill level: high, medium and low. We estimate augmented production function where the malefemale wage differentials constitute a potential channel influencing growth (positively or negatively). Our research is motivated by the ambiguous results of previous empirical studies (e.g.: Seguiono 2000; Busse, Spielmann 2006; Seguino 2011; Schober, Winter-Ebmer 2011). Our main findings indicate that gender wage gap for high, medium and low-skilled workers is negatively correlated with sectoral growth. This results are confirmed in a number of robustness checks.
\end{abstract}

(C) Copyright Institute of Economic Research \& Polish Economic Society Branch in Toruń

Date of submission: March 1, 2013; date of acceptance: July 22, 2013

* Contact: jwo@zie.pg.gda.pl, Gdańsk University of Technology, Narutowicza 11/12, 80233, Gdansk, Poland

** The research was performed under (Polish) National Science Centre's project: "Gender wage discrimination: size, determinants and consequences - an analysis of sectoral wage differences in OECD countries", No. DEC-2011/01/B/HS4/04809.

The paper has benefited from the comments of participants of VII International Conference on Applied Economics - Contemporary issues in economy, Torun - May 2013. Finally, the author acknowledges comments and suggestions from anonymous referees. 


\section{Introduction}

There is a general agreement that gender inequality is harmful not only from the perspective of a given discriminated individual and her well-being, but also for the economy as a whole. This belief is the underpin of policy actions that focus on promoting female/male equity taking into account economic, political, educational and health-based context ${ }^{1}$. The main message of the latest World Development Report is that gender equity matters for development:

"Gender equality is a core development objective in its own right. It is also smart economics. Greater gender equality can enhance productivity, improve development outcomes for the next generation, and make institutions more representative." (World Bank 2011, p. XX).

However, the relationship between the economic growth and gender inequality is complex, being a consequence of direct and indirect factors. The vast part of the feminist literature focused on unequal access of females to education (among others: Klasen (2002), Klasen and Lamanna (2009), Knowles et al. (2002)). If females have a restricted access to the education, it will lower the overall human capital which is harming for economic growth. Additionally, female education can impact long-run economic growth through reduced fertility, lower child mortality and better perspectives for the next generations (Berik et al. 2009). In a similar manner, the restricted access to the labor market can impact negatively the economic growth, as the optimal allocation of resources is distorted.

In this paper, we concentrate on the gender wage gap understood as different level of remuneration of women and men that is not explained by the differences in their productivity.

The theoretical background of our study is Becker's discrimination theory (Becker 1971), in which gender wage gap occurs as a result of employers' taste of discrimination - employers are willing to pay over marginal productivity due to their preferences. Comparison of profits of discriminating and nondiscriminating firms is in favor of the latter. Thus, decrease of productivity (slower growth) is one of the main outcomes of discrimination.

However, there are a few channels through which female-male wage differentials can influence economic growth. First of all, it is argued (Seguiono

\footnotetext{
${ }^{1}$ For example incentives of International Labour Organistation (see projects of Bureau for Gender Equality), World Bank (e.g.: Gender Equality Agenda at the World Bank Group), United Nations (Goal 3 of Millennium Development Goals is dedicated to the promotions of gender equity and empowerment women), and others. At the European level activities are carried under the auspices of European Commission Directorate-General for Justice, Directorate General for Employment, Social Affairs and Inclusion, European Parliament Committee on Women's Rights and Gender Equality, and The European Institute for Gender Equality.
} 
2000) that gender wage inequality through export expansion can stimulate country's growth. The mechanism of this unintuitive hypothesis is quite simple. For example, if export is based on labor-intensive goods, then lower remuneration of work force intensively used for its production (e.g. women) would spur its price competitiveness and lead to export expansion. Then, income from export earnings can provide the financial resources to produce/purchase new technologies and hence stimulate a country's growth. In a similar manner, the gender wage gap can lead to higher investments.

A contrary view is based on the prediction that income inequality (also gender inequality) can produce social conflict that may retard economic growth. For example, higher difference in wages obtained by men and women might discourage women from entering labour market and hence influence women's fertility decision. If women are paid lower wages then opportunity cost of children decreases which can lead to higher population growth, decreased capital per worker and a slowdown of economic growth (World Bank 2011).

Further, then women's consumption pattern is different from men and they tend to spend more of their income on children's education and health, which can also affect development in long run (Pervaiz et al. 2011). Reducing gender wage gap can enhance women's labour participation, and they will spend their earning rather on children's education and health, and this investment in the future generation will create more productive and efficient labour force for the future, which will be beneficial for long-run growth.

We can see that starting from the theoretical point of view, the wage gap can either influence economic growth negatively or positively, and in consequence the overall effect is ambiguous.

Additionally, the empirical studies on gender wage gap and economic growth nexus are far from conclusive. In the seminal paper (Seguion 2000) analyzed 20 semi-industrialized countries during 1975-1995 and showed that GDP growth and investments were positively related to gender wage inequality. The author explains it by the export lead hypothesis. However, these controversial results were thoroughly discussed in literature. Busse and Spielmann (2006) confirmed the positive linkages between gender inequality and trade flows on a sample of 92 developed and developing countries. They showed that the countries with a larger gender wage gap have higher exports of the labor-intensive manufactured goods. Contrary, Schober and WinterEbmer (2011) replicated the Seguino's empirical analysis with the use of different character of the data. They used the data coming from a metaregression on the international gender wage gap (Weichselbaumer, WinterEbmer 2005), and none of their regressions showed any positive impact of gender wage discrimination on the economic growth. In a reply to Schober and Winter-Ebmer, Seguino (2011) questions the quality of data based on 
heterogeneous micro-level studies, discussed the possible measurement errors that such data introduce and notes concerns with the meta-regression they performed. She concludes that to test the hypothesis of the impact of the gender wage differentials on the growth, one should take into account education-adjusted wages from manufacturing sectors.

In view of this discussion, we propose an empirical analysis of testing the gender wage gap and economic growth nexus on the basis of 12 manufacturing sectors in 18 OECD countries for the period between 1970 and 2005. We use industrial statistics (EU KLEMS 2008) on female and male wages that distinguish between wages paid to different groups of workers classified according to skill level: high, medium and low The base of our empirical analysis is augmented production function where the male-female wage differentials constitute a potential channel influencing growth.

The main hypothesis to be tested is the negative correlation between gender wage gap and productivity growth: other things being equal, higher the differences between female/male wages, slower the rate of productivity growth. The hypothesis is going to be tested for wages of three different skill categories: low, medium and high.

The rest of the paper is structured as follows: in Section 2, we present data and describe the trends in the female/male wage ratio across different industries, and skill specifications, in Section 3 we estimate an augmented production function revealing the effects of gender wage differentials on the evolution of sectoral growth, together with numerous robustness checks. Finally, Section 4 concludes.

\section{The Trend in the Female/Male Wage Ratio Across Countries and Across Industries}

One of the main difficulties of cross-country studies considering gender wage gap is the limited access to the comparable data on female and male wages at relatively disaggregated industry level (see discussion in Seguino (2011) and Schober and Winter-Ebmer (2011)). In this study, we use data coming from the EU KLEMS, 2008 on female and male wages that distinguish between wages paid to different groups of workers classified according to skill level: high, medium and low. The macroeconomic nature of the dataset has its price. We do not possess information about education, qualification, experience, etc. that would make it possible to calculate the residual gender wage gap, i.e. the gender wage gap that remains after controlling for differences in those factors. Because of that we are forced to assume that female and male workers have similar abilities in the three skill categories (low, medium and high), and, consequently, we treat gender wage differen- 
tials as a proxy for the residual wage gap. A similar approach has been taken in other macroeconomic studies (e.g. Oostendorp 2009; DominguezVillalobos, Brown-Grossman 2010; Wolszczak-Derlacz 2013). The data take into account 34 industries (12 manufacturing) from 18 OECD countries for the period between 1970 and 2005. Table 1 and 2 in the Appendix present the final country and sector composition of our panel.

The rest of the sector-specific data: value added, labour, gross fixed capital formation also come from the EU KLEMS 2008. We use country- and industry-specific price indices to report all nominal values in constant terms $(1995=1)$. The data on imports and exports come from the OECD STAN (2009 release). The country-level data on human capital are retrieved from the UNCTAD database, which in turn is based on interpolation and extrapolation of Barro and Lee's (2013) dataset.

Table 1 presents female/male wage ratio of high-skilled, medium-skilled and low-skilled workforce, by sector in 1970 and 2005. At all skill levels and in all industries, women earn significantly less than men. Taking into consideration total economy, the greatest differences are for low-skilled workers, where on average in 2005 women's earnings represented around 72 per cent of men's earnings and the smallest for medium-skilled workforces, where women's wages constituted 79 per cent of men's ones. When we compare gender wage gap across industries and skill categories then, for high-skilled and medium-skilled workers, the biggest difference in 2005 were for financial intermediation (female/male ratio of 0.668 and 0.732 respectively) and for low-skilled workers - maintenance and repair of motor vehicles and motorcycles 0.686. Between 1970 and 2005, the biggest increase in the ratio of female/male earning was experienced in real estate activities (both for high and medium skilled categories)., where the figure rose by 86 and $45 \%$ respectively, while for the low-skilled workers by $20 \%$. However it should be noted that despite the general trend of an increasing trend in the female-to-male earnings ratio, there are cases where the drop in the figures was observed e.g. high-skilled workers in agriculture experienced a decrease in the ratio, the same is true for medium and low skilled workers from sale, maintenance and repair of motor vehicles and motorcycles sector. 
Table 1. Female/male wage ratio of high-skilled, medium-skilled and low-skilled workforce, by sector in 1970 and 2005, (all countries pooled together)

\begin{tabular}{|c|c|c|c|c|c|c|}
\hline \multirow[b]{2}{*}{ Sectors } & \multicolumn{3}{|c|}{1970} & \multicolumn{3}{|c|}{2005} \\
\hline & $\begin{array}{c}\text { High } \\
\text { Skilled }\end{array}$ & $\begin{array}{c}\text { Medium } \\
\text { skilled }\end{array}$ & $\begin{array}{c}\text { Low } \\
\text { skilled }\end{array}$ & $\begin{array}{c}\text { High } \\
\text { skilled }\end{array}$ & $\begin{array}{c}\text { Medium } \\
\text { skilled }\end{array}$ & $\begin{array}{c}\text { Low } \\
\text { skilled }\end{array}$ \\
\hline $15 \mathrm{t} 16$ & 0.594 & 0.661 & 0.674 & 0.722 & 0.738 & 0.723 \\
\hline $17 \mathrm{t} 19$ & 0.580 & 0.668 & 0.694 & 0.710 & 0.742 & 0.736 \\
\hline 20 & 0.638 & 0.762 & 0.669 & 0.780 & 0.818 & 0.767 \\
\hline $21 \mathrm{t} 22$ & 0.576 & 0.669 & 0.585 & 0.753 & 0.793 & 0.746 \\
\hline 24 & 0.570 & 0.654 & 0.626 & 0.734 & 0.790 & 0.772 \\
\hline 25 & 0.623 & 0.682 & 0.652 & 0.731 & 0.781 & 0.770 \\
\hline 26 & 0.567 & 0.667 & 0.606 & 0.720 & 0.794 & 0.750 \\
\hline $27 \mathrm{t} 28$ & 0.515 & 0.668 & 0.581 & 0.736 & 0.797 & 0.768 \\
\hline 29 & 0.597 & 0.671 & 0.663 & 0.729 & 0.784 & 0.787 \\
\hline 30 t33 & 0.591 & 0.654 & 0.663 & 0.732 & 0.775 & 0.788 \\
\hline $34 \mathrm{t} 35$ & 0.597 & 0.690 & 0.689 & 0.729 & 0.776 & 0.773 \\
\hline $36 \mathrm{t} 37$ & 0.555 & 0.703 & 0.691 & 0.738 & 0.773 & 0.747 \\
\hline 50 & 0.554 & 0.810 & 0.999 & 0.682 & 0.775 & 0.686 \\
\hline 51 & 0.533 & 0.692 & 0.658 & 0.702 & 0.763 & 0.697 \\
\hline 52 & 0.519 & 0.599 & 0.550 & 0.780 & 0.774 & 0.746 \\
\hline $60 \mathrm{t} 63$ & 0.626 & 0.698 & 0.638 & 0.751 & 0.872 & 0.794 \\
\hline 64 & 0.666 & 0.657 & 0.648 & 0.761 & 0.811 & 0.740 \\
\hline 70 & 0.483 & 0.617 & 0.664 & 0.897 & 0.893 & 0.793 \\
\hline $71 \mathrm{t} 74$ & 0.613 & 0.627 & 0.629 & 0.730 & 0.821 & 0.721 \\
\hline AtB & 0.919 & 0.728 & 0.718 & 0.870 & 0.854 & 0.760 \\
\hline $\mathrm{C}$ & 0.586 & 0.652 & 0.587 & 0.714 & 0.809 & 0.748 \\
\hline $\mathrm{D}$ & 0.569 & 0.652 & 0.632 & 0.741 & 0.757 & 0.736 \\
\hline E & 0.562 & 0.661 & 0.593 & 0.750 & 0.799 & 0.735 \\
\hline $\mathrm{F}$ & 0.598 & 0.623 & 0.596 & 0.740 & 0.881 & 0.761 \\
\hline G & 0.516 & 0.616 & 0.546 & 0.698 & 0.758 & 0.724 \\
\hline $\mathrm{H}$ & 0.608 & 0.600 & 0.588 & 0.687 & 0.764 & 0.763 \\
\hline I & 0.620 & 0.675 & 0.674 & 0.763 & 0.868 & 0.774 \\
\hline
\end{tabular}


Table 1 continued

\begin{tabular}{|l|r|r|r|r|r|r|}
\cline { 2 - 7 } \multicolumn{1}{c|}{} & \multicolumn{3}{c|}{$\mathbf{1 9 7 0}$} & \multicolumn{3}{c|}{$\mathbf{2 0 0 5}$} \\
\hline Sectors & $\begin{array}{c}\text { High } \\
\text { Skilled }\end{array}$ & \multicolumn{1}{c|}{$\begin{array}{c}\text { Medium } \\
\text { skilled }\end{array}$} & $\begin{array}{c}\text { Low } \\
\text { skilled }\end{array}$ & $\begin{array}{c}\text { High } \\
\text { skilled }\end{array}$ & $\begin{array}{c}\text { Medium } \\
\text { skilled }\end{array}$ & \multicolumn{1}{c|}{$\begin{array}{c}\text { Low } \\
\text { skilled }\end{array}$} \\
\hline J & 0.468 & 0.580 & 0.651 & 0.668 & 0.732 & 0.721 \\
\hline K & 0.574 & 0.606 & 0.616 & 0.738 & 0.839 & 0.748 \\
\hline L & 0.663 & 0.748 & 0.573 & 0.761 & 0.804 & 0.769 \\
\hline M & 0.757 & 0.735 & 0.580 & 0.819 & 0.850 & 0.763 \\
\hline N & 0.582 & 0.801 & 0.688 & 0.752 & 0.854 & 0.847 \\
\hline O & 0.739 & 0.586 & 0.528 & 0.748 & 0.751 & 0.700 \\
\hline P & 0.645 & 0.569 & 0.493 & 0.741 & 0.745 & 0.779 \\
\hline TOT & 0.733 & 0.733 & 0.627 & 0.754 & 0.795 & 0.726 \\
\hline
\end{tabular}

Source: own calculations based on data from EU KLEMS 2008.

It is also worth examining the wage gap for the manufacturing sectors more closely. Generally, for the aggregate of manufacturing sectors the female/male ratio rose by $30 \%$ for high skilled workers and by around $15 \%$ for medium and low-skilled workers. The highest increase between 1970 and 2005 was observed for the sector of basic metals and fabricated metal products both for high skilled and low skilled workers which, however, were starting from the lowest point in 1970 (women's earnings represented around 50 and 58 per cent of men's earnings respectively). Among manufacturing sectors in 2005 the lowest female/male wage ratio for high skilled workers is for textiles, while for medium and low skilled workers for food products, beverages and tobacco.

There are, of course, cross-country differences which were not shown in Table 1. Table 2 provides description of the female/male wage ratio in the countries analysed, calculated as the average value for all sectors in 2005 . For high-skilled workers (first column) the ratio varies from 0.632 in Poland to 0.927 in Austria. Similarly, Austria has the lowest gender wage gap (highest female/male ratio) for medium and low-skilled workers, for example for the latter group in 2005 women's earnings were equal to men's. 
Table 2. Female/male wage ratio of high-skilled, medium-skilled and low-skilled in 2005, average across sectors

\begin{tabular}{|l|r|r|r|}
\cline { 2 - 4 } \multicolumn{1}{c|}{} & \multicolumn{1}{c|}{$\begin{array}{c}\text { High- } \\
\text { skilled }\end{array}$} & \multicolumn{1}{c|}{$\begin{array}{c}\text { Medium- } \\
\text { skilled }\end{array}$} & \multicolumn{1}{c|}{$\begin{array}{c}\text { Low- } \\
\text { skilled }\end{array}$} \\
\hline AUS & 0.761 & 0.700 & 0.747 \\
\hline AUT & 0.927 & 0.987 & 1.003 \\
\hline BEL & 0.690 & 0.750 & 0.692 \\
\hline CZE & 0.716 & 0.735 & 0.743 \\
\hline DNK & 0.719 & 0.807 & 0.854 \\
\hline ESP & 0.653 & 0.731 & 0.701 \\
\hline FIN & 0.653 & 0.760 & 0.790 \\
\hline GER & 0.644 & 0.690 & 0.625 \\
\hline HUN & 0.775 & 0.912 & 0.851 \\
\hline ITA & 0.908 & 0.924 & 0.659 \\
\hline JPN & 0.661 & 0.678 & 0.627 \\
\hline KOR & 0.669 & 0.766 & 0.758 \\
\hline NLD & 0.810 & 0.852 & 0.839 \\
\hline POL & 0.632 & 0.799 & 0.716 \\
\hline SVK & 0.679 & 0.749 & 0.732 \\
\hline SVN & 0.791 & 0.887 & 0.846 \\
\hline UK & 0.735 & 0.612 & 0.596 \\
\hline USA & 0.675 & 0.748 & 0.755 \\
\hline
\end{tabular}

Source: own calculations based on data from EU KLEMS 2008

\section{Empirical Analysis}

\section{Empirical setting}

We start from the classical production function augmented by the introduction of female and male labour force:

$$
Y_{i j, t}=A_{i j, t} F\left(K_{i j, t}, L_{i j, t}^{f}, L_{i j, t}^{m}\right),
$$

where $Y_{i j, t}$ is the value added of sector $j$ in country $i$, produced at time $t$ with physical capital $\left(K_{i j, t}\right)$ and labour input that is the sum of female and male 
workers $L_{i j, t}=\left(L_{i j, t}^{f}+L_{i j, t}^{m}\right)$ which are assumed to be perfect substitutes in production; $A_{i j, t}$ is an index of technical efficiency or total factor productivity (TFP). We assume the function $F$ to be homogenous of degree one and characterized by diminishing marginal returns to the accumulation of $K$ and $L$ respectively. Following Seguino (2000), we model TFP as the function of external factors and gender wage gap:

$$
A_{i j, t}=C_{i j}(1+X t) e^{\delta W G A P},
$$

where: $C_{\mathrm{ij}}$ - is is the country-sector specific time-invariant effect, $X$-reflects all other factors which influence the productivity growth, WGAP is the gender wage gap. We substitute (2) into (1), take natural logs and differentiate with respect to time which yields the final version of our empirical model:

$$
\begin{aligned}
& \Delta y_{i j t}=\beta_{1} \Delta l_{i j t}^{f}+\beta_{2} \Delta l_{i j t}^{m}+\beta_{2} \Delta k_{i j t}+\beta X_{i j, t}+ \\
& +\delta W G A P+v_{t}+c_{i j}+e_{i j t}
\end{aligned}
$$

where the lower letters are used to express logs of a given variables, $v_{t}$ is the time specific intercept reflecting for example a common technology shock or business cycle fluctuation. $c_{i j}$ is an unobserved time invariant sector/country specific effect. This growth model (3) is in line with the econometric approach of productivity growth measure. It shows which country would have higher productivity growth rate when the differences in capital and labour growth have been taken into account. It should be noted that however we assume the substitution between female and male labour, we treat them as separate inputs (for a discussion of production function with disaggregated labour inputs see e.g Field-Hendrey 1998 or for CES function - Acemoglu et al. 2004).

The coefficient we are mainly interested in is $\delta$, which measures the relationship between gender wage gap and the growth rate. We define the gender wage gap $(W G A P)$ as the log-wage differential between males $(M)$ and females $(F)$ possessing comparable skills:

$$
W G A P=w_{i j, t}^{S}=\ln W_{i j, t}^{M, S}-\ln W_{i j, t}^{F, S},
$$

where, as before $i$ refers to sector, $j$ to country, $S$ to skill classification (highskilled wage- $w^{h s}$, medium-skilled wage- $w^{m s}$ and low-skilled wage- $w^{l s}$ ) and $t$ to time period. Note that the wage gap expressed in (4) is reversal of the female/male wage ratio introduced in the previous section, hence the nega- 
tive value of the parameter $\delta$ would indicate that higher gender wage gap is connected with the lower rate of growth and vice versa.

Among other factors that may have an impact on the economic growth $X_{i j, t}$ we include trade openness of a given sector and proxy of human capital. For the trade variable, we used the ratio of imports and export to value added, while human capital is measured as the relative skill intensity defined as the share of hours worked by persons with higher education both women and men, of the total hours worked.

\section{Results}

The first step in our analysis is to investigate the time series properties of the variables in order to avoid a spurious regression. We apply panel unit roots, which have higher power than those based on individual time series, especially when the latter are not very long. Because our panel is not balanced, we opt for Fisher-type tests - a suitable approach for testing for panel-data unit roots from a meta-analysis perspective which does not require a balanced dataset. We employ two different versions of the test: ADF and Phillips-Perron with and without trend. The outcomes of these tests, presented in Table A3 in Appendix, indicate no evidence of unit roots in most of our variables and thus spurious regression should not be a problem in the empirical analysis which follows.

As far as estimation strategy is concerned, based on the Hausman test most of the calculations are going to be performed under fixed effects model with an additional time dummies.

We start with the plain regression, which on the right hand side of the specification takes into account only labour inputs and the measure of gender wage gap, capital stock or any other explanatory variables are not included (Table 3 Columns (1) to (4)). The coefficients in front of labour inputs (measured by the number of hours worked by females and males respectively) are positive and highly significant as expected. The main concern of this paper is the role of gender wage gap in the economic growth. Firstly, we include in the regression the skill specific gender wage gap separately (Columns (1) to (3), then in Column (4) they are introduced simultaneously). For all skill classification, we have found a negative and statistically significant coefficient - the higher the gender wage gap, the lower the rate of sectoral growth. An increase in gender wage gap by 1 percent translates into a decrease in average growth rate of between 0.058 to 0.015 percentage points - taking into consideration that the average value of growth rate is 0.04 the effect seems to be economically significant. 
Table 3. The determinants of economic growth $(\Delta \mathrm{yij}, \mathrm{t})$

\begin{tabular}{|c|c|c|c|c|c|c|c|c|c|c|c|c|}
\hline & (1) & (2) & (3) & (4) & (5) & (6) & (7) & (8) & (9) & (10) & (11) & (12) \\
\hline \multirow[t]{2}{*}{$\Delta \mathrm{l}_{\mathrm{ij}, \mathrm{t}}^{\mathrm{f}}$} & $\begin{array}{l}0.090 \\
* *\end{array}$ & $\begin{array}{l}0.093 \\
* *\end{array}$ & $\begin{array}{l}0.098^{*} \\
*\end{array}$ & $\begin{array}{l}0.099 * \\
*\end{array}$ & 0.047 & $0.065^{*}$ & 0.057 & $0.068^{*}$ & $\begin{array}{l}0.083 \\
* *\end{array}$ & $\begin{array}{l}0.091 * \\
*\end{array}$ & $\begin{array}{l}0.088 \\
* *\end{array}$ & $\begin{array}{l}0.092^{*} \\
*\end{array}$ \\
\hline & $\begin{array}{l}{[0.040} \\
]\end{array}$ & $\begin{array}{l}{[0.040} \\
]\end{array}$ & $\begin{array}{l}{[0.040} \\
]\end{array}$ & $\begin{array}{l}{[0.040} \\
]\end{array}$ & $\begin{array}{l}{[0.036} \\
]\end{array}$ & $\begin{array}{l}{[0.036} \\
]\end{array}$ & $\begin{array}{l}{[0.036} \\
]\end{array}$ & $\begin{array}{l}{[0.036} \\
]\end{array}$ & $\begin{array}{l}{[0.040} \\
]\end{array}$ & $\begin{array}{l}{[0.040} \\
]\end{array}$ & $\begin{array}{l}{[0.039} \\
]\end{array}$ & $\begin{array}{l}{[0.040} \\
]\end{array}$ \\
\hline \multirow[t]{2}{*}{$\begin{array}{l}\Delta \mathrm{l}^{\mathrm{m}} \mathrm{ij}, \\
\mathrm{t}\end{array}$} & $\begin{array}{l}0.271 \\
* * *\end{array}$ & $\begin{array}{l}0.267 \\
* * *\end{array}$ & $\begin{array}{l}0.261^{*} \\
* *\end{array}$ & $\begin{array}{l}0.262^{*} \\
* *\end{array}$ & $\begin{array}{l}0.479 \\
* * *\end{array}$ & $\begin{array}{l}0.477 * \\
* *\end{array}$ & $\begin{array}{l}0.466^{*} \\
* *\end{array}$ & $\begin{array}{l}0.471^{*} \\
* *\end{array}$ & $\begin{array}{l}0.265 \\
* * *\end{array}$ & $\begin{array}{l}0.257^{*} \\
* *\end{array}$ & $\begin{array}{l}0.260 \\
* * *\end{array}$ & $\begin{array}{l}0.257^{*} \\
* *\end{array}$ \\
\hline & $\begin{array}{l}{[0.092} \\
]\end{array}$ & $\begin{array}{l}{[0.091} \\
]\end{array}$ & $\begin{array}{l}{[0.091} \\
]\end{array}$ & $\begin{array}{l}{[0.092} \\
]\end{array}$ & $\begin{array}{l}{[0.057} \\
]\end{array}$ & $\begin{array}{l}\text { [0.057 } \\
]\end{array}$ & $\begin{array}{l}{[0.057} \\
]\end{array}$ & $\begin{array}{l}{[0.057} \\
]\end{array}$ & $\begin{array}{l}{[0.096} \\
]\end{array}$ & $\begin{array}{l}\text { [0.095 } \\
]\end{array}$ & $\begin{array}{l}{[0.095} \\
]\end{array}$ & $\begin{array}{l}{[0.096} \\
]]\end{array}$ \\
\hline \multirow[t]{2}{*}{$\begin{array}{l}\mathrm{W}^{\mathrm{HS}}{ }_{\mathrm{i}} \\
\mathrm{j}, \mathrm{t}\end{array}$} & $\begin{array}{l}- \\
0.015 \\
*\end{array}$ & & & -0.001 & $\begin{array}{l}- \\
0.023 \\
* *\end{array}$ & & & $\overline{0.019 *}$ & $\begin{array}{l}- \\
0.021 \\
* *\end{array}$ & & & -0.009 \\
\hline & $\begin{array}{l}{[0.009} \\
]\end{array}$ & & & $\begin{array}{l}{[0.009} \\
]\end{array}$ & $\begin{array}{l}{[0.011} \\
]\end{array}$ & & & $\begin{array}{l}{[0.011} \\
]\end{array}$ & $\begin{array}{l}{[0.010} \\
]\end{array}$ & & & $\begin{array}{l}{[0.009} \\
]\end{array}$ \\
\hline \multirow[t]{2}{*}{$\begin{array}{l}\mathrm{W}^{\mathrm{MS}}{ }_{\mathrm{i}} \\
\mathrm{j}, \mathrm{t}\end{array}$} & & $\begin{array}{l}- \\
0.058 \\
* *\end{array}$ & & $\begin{array}{l}- \\
0.045^{*} \\
* *\end{array}$ & & $\begin{array}{l}- \\
0.107 * \\
* *\end{array}$ & & $\begin{array}{l}- \\
0.067^{*} \\
* *\end{array}$ & & $\begin{array}{l}- \\
0.060^{*} \\
* *\end{array}$ & & $\begin{array}{l}- \\
0.048^{*} \\
* *\end{array}$ \\
\hline & & $\begin{array}{l}{[0.014} \\
]\end{array}$ & & $\begin{array}{l}{[0.013} \\
]\end{array}$ & & $\begin{array}{l}{[0.020} \\
]\end{array}$ & & $\begin{array}{l}{[0.019} \\
]\end{array}$ & & $\begin{array}{l}{[0.016} \\
]\end{array}$ & & $\begin{array}{l}{[0.016} \\
]\end{array}$ \\
\hline \multirow[t]{2}{*}{$\begin{array}{l}\mathrm{W}^{\mathrm{LS}}{ }_{\mathrm{ij}} \\
\mathrm{t}\end{array}$} & & & $\begin{array}{l}- \\
0.043^{*} \\
* *\end{array}$ & $\begin{array}{l}- \\
0.030^{*} \\
* *\end{array}$ & & & $\begin{array}{l}- \\
0.069^{*} \\
* *\end{array}$ & $\begin{array}{l}- \\
0.051^{*} \\
* *\end{array}$ & & & $\begin{array}{l}- \\
0.034 \\
* *\end{array}$ & -0.019 \\
\hline & & & $\begin{array}{l}{[0.012} \\
]\end{array}$ & $\begin{array}{l}{[0.010} \\
]\end{array}$ & & & $\begin{array}{l}{[0.018} \\
]\end{array}$ & $\begin{array}{l}{[0.015} \\
]\end{array}$ & & & $\begin{array}{l}{[0.013} \\
]\end{array}$ & $\begin{array}{l}{[0.012} \\
]\end{array}$ \\
\hline \multirow[t]{2}{*}{$\Delta \mathrm{k}_{\mathrm{ij}, \mathrm{t}}$} & & & & & 0.033 & 0.031 & 0.044 & 0.036 & & & & \\
\hline & & & & & $\begin{array}{l}{[0.043} \\
]\end{array}$ & $\begin{array}{l}{[0.043} \\
]\end{array}$ & $\begin{array}{l}{[0.044} \\
]\end{array}$ & $\begin{array}{l}{[0.043} \\
]\end{array}$ & & & & \\
\hline \multirow[t]{2}{*}{$\begin{array}{l}\text { Trad } \\
\mathrm{e}_{\mathrm{ij}, \mathrm{t}}\end{array}$} & & & & & & & & & 0.004 & 0.006 & 0.003 & 0.006 \\
\hline & & & & & & & & & $\begin{array}{l}{[0.009} \\
]\end{array}$ & $\begin{array}{l}{[0.009} \\
]\end{array}$ & $\begin{array}{l}{[0.009} \\
]\end{array}$ & $\begin{array}{l}{[0.009} \\
]\end{array}$ \\
\hline \multirow[t]{2}{*}{$\begin{array}{l}\mathrm{HC} \\
\mathrm{ij}, \mathrm{t}\end{array}$} & & & & & & & & & $\begin{array}{l}0.021 \\
* *\end{array}$ & $\begin{array}{l}0.019 * \\
*\end{array}$ & $\begin{array}{l}0.018 \\
*\end{array}$ & $0.018^{*}$ \\
\hline & & & & & & & & & $\begin{array}{l}{[0.009} \\
]\end{array}$ & $\begin{array}{l}{[0.009} \\
]\end{array}$ & $\begin{array}{l}{[0.009} \\
]\end{array}$ & $\begin{array}{l}{[0.009} \\
]\end{array}$ \\
\hline $\mathrm{R}^{2}$ & 0.104 & 0.106 & 0.105 & 0.106 & 0.199 & 0.204 & 0.203 & 0.207 & 0.105 & 0.106 & 0.105 & 0.106 \\
\hline $\mathrm{N}$ & 6929 & 6947 & 6947 & 6929 & 3616 & 3631 & 3631 & 3616 & 6639 & 6657 & 6657 & 6639 \\
\hline
\end{tabular}

Notes: all computations made using StataSE 9.0. Sector/country effects and time dummies included in all specifications. Constant not reported.

Robust standard errors in parentheses. Statistically significant at $* * * 1, * * 5, * 10$ percent level

Source: own estimation.

Columns (5) to (8) report the results when the capital stock is included. The capital stock was calculated using the perpetual inventory method with the utilization of gross fixed capital formation and a depreciation rate of $6 \%$ (see, for example, Caselli, 2005 for a description of methodology). Note the drop in the number of observation - there is no data for Australia, Japan and Korea. Although we have not obtained statistically significant parameter of the growth of capital, the correlation of gender wage gap of different skill categories with economic growth is confirmed - in each case we have obtained a negative and statistically significant parameter. 
Next, we augment the regression with other variables that can have an impact on the economic growth (Columns (9) to (12). Among the variables that can impact economic growth we include trade penetration (measured as the ratio of import and export to the sectoral value added) and human capital expressed as the skill intensity (defined as the share of hours worked by persons with higher education both women and men, of the total hours worked). We have obtained positive and significant coefficients only for human capital. In case of trade, we cannot prove its positive correlation with economic growth. However, the negative association between high, medium, low skilled wage differentials and growth is sustained.

We check the stability of our conclusion by number of model alternation. First of all, we consider an alternative measure of human capital - the average number of years of schooling. The data are obtained from the UNCTAD database, which in turn is based on interpolation and extrapolation of Barro and Lee's (2013) dataset. ${ }^{2}$ Due to data availability, this variable is country specific. The results are presented in Table 4. The estimated coefficients are similar to the previous ones - with the exception of the human capital variable whose magnitudes are much higher now. It can be explained by possible externalities of human capital across sectors.

In the previous estimation, we have not obtained a statistically significant parameter on openness when the variable was represented by total trade: import plus export and when the fixed effects were employed. We check this through employing separately import and export penetration instead of the sum of trade flows, as import and export can have different impact on the growth. However, again we did not obtain a statistically significant coefficient neither for import penetration nor for export penetration Nevertheless, the findings considering the negative correlation between skill-specific wage gap and growth rate are in line with the previous estimations.

2 The database can be downloaded from UNCTAD website (http://r0.unctad.org/ditc/tab/index.shtm), this version May 2011. The yearly figures were obtained through interpolation and extrapolation of Barro and Lee's (2013) dataset (because Barro and Lee (2013) report values only for each five years). 
Table 4. The determinants of economic growth $\left(\Delta \mathrm{y}_{\mathrm{ij}, \mathrm{t}}\right)$, human capital measured as - the average number of years of schooling

\begin{tabular}{|c|c|c|c|c|}
\hline & (1) & (2) & (3) & (4) \\
\hline \multirow[t]{2}{*}{$\Delta \mathrm{l}_{\mathrm{ij}, \mathrm{t}}^{\mathrm{f}}$} & $0.1216^{* * *}$ & $0.1245^{* * *}$ & $0.1290^{* * *}$ & $0.1301 * * *$ \\
\hline & [0.0407] & {$[0.0400]$} & {$[0.0405]$} & {$[0.0400]$} \\
\hline \multirow[t]{2}{*}{$\Delta \mathrm{l}_{\mathrm{ij}, \mathrm{t}}^{\mathrm{m}}$} & $0.3903 * * *$ & $0.3858 * * *$ & $0.3787 * * *$ & $0.3813 * * *$ \\
\hline & [0.0931] & [0.0914] & [0.0913] & {$[0.0926]$} \\
\hline \multirow[t]{2}{*}{$\mathrm{HC}_{\mathrm{i}, \mathrm{t}}$} & $0.4688 * * *$ & $0.4582 * * *$ & $0.4769 * * *$ & $0.4682 * * *$ \\
\hline & {$[0.1655]$} & {$[0.1640]$} & {$[0.1645]$} & {$[0.1641]$} \\
\hline \multirow[t]{2}{*}{$\mathrm{W}^{\mathrm{HS}}{ }_{\mathrm{ij}, \mathrm{t}}$} & $-0.0186^{* *}$ & & & -0.0067 \\
\hline & {$[0.0091]$} & & & {$[0.0090]$} \\
\hline \multirow[t]{2}{*}{$\mathrm{W}^{\mathrm{MS}}$} & & $-0.0516 * * *$ & & $-0.0374 * * *$ \\
\hline & & [0.0130] & & {$[0.0127]$} \\
\hline \multirow[t]{2}{*}{$\mathrm{W}^{\mathrm{LS}}{ }_{\mathrm{ij}, \mathrm{t}}$} & & & $-0.0409 * * *$ & $-0.0297 * * *$ \\
\hline & & & {$[0.0122]$} & {$[0.0101]$} \\
\hline $\mathrm{R}^{2}$ & 0.137 & 0.139 & 0.138 & 0.14 \\
\hline $\mathrm{N}$ & 6108 & 6126 & 6126 & 6108 \\
\hline
\end{tabular}

Notes: all computations made using StataSE 9.0.Constant not reported.

Robust standard errors in parentheses. Statistically significant at $* * * 1, * * 5, * 10$ percent level

Source: own estimation.

The next robustness check involves the country, industry and time composition of our analysis. We performed the analysis for sub-sample of European countries, for the 1980-2005 and 1990-2005 subsamples and sequentially excluding industries one by one to check the sensitivity of the results for specific industries - in most of the specifications (with or without additional right-hand side variables: capital stock, trade, human capital) we obtained a negative and statistically significant coefficients on skill specific gender wage gap.

The results for subsample of European counties are presented in Table 5. 
Table 5. The determinants of economic growth $\left(\Delta \mathrm{y}_{\mathrm{ij}, \mathrm{t}}\right)-$ European countries

\begin{tabular}{|c|c|c|c|c|}
\hline & (1) & (2) & (3) & (4) \\
\hline \multirow[t]{2}{*}{$\Delta \mathrm{l}_{\mathrm{ij}, \mathrm{t}}^{\mathrm{f}}$} & 0.0442 & 0.0523 & 0.0463 & 0.0511 \\
\hline & {$[0.0446]$} & {$[0.0445]$} & {$[0.0438]$} & {$[0.0450]$} \\
\hline \multirow[t]{2}{*}{$\Delta \mathrm{l}_{\mathrm{ij}, \mathrm{t}}^{\mathrm{m}}$} & $0.2494 * *$ & $0.2432 * *$ & $0.2473 * *$ & $0.2449 * *$ \\
\hline & {$[0.1050]$} & {$[0.1038]$} & [0.1044] & [0.1044] \\
\hline \multirow[t]{2}{*}{$\mathrm{W}_{\mathrm{ij}, \mathrm{t}}^{\mathrm{HS}}$} & $-0.0218 * *$ & & & -0.0147 \\
\hline & {$[0.0101]$} & & & {$[0.0091]$} \\
\hline \multirow[t]{2}{*}{$\mathrm{W}^{\mathrm{MS}}$} & & $-0.0636 * *$ & & $-0.0542 *$ \\
\hline & & {$[0.0279]$} & & {$[0.0356]$} \\
\hline \multirow[t]{2}{*}{$\mathrm{W}^{\mathrm{LS}}{ }_{\mathrm{ij}, \mathrm{t}}$} & & & $-0.0233 *$ & $-0.001^{*}$ \\
\hline & & & {$[0.0120]$} & {$[0.0158]$} \\
\hline \multirow[t]{2}{*}{ Tradeij,t } & 0.0039 & 0.0062 & 0.0035 & 0.0063 \\
\hline & [0.0132] & [0.0137] & [0.0130] & [0.0139] \\
\hline \multirow[t]{2}{*}{$\mathrm{HC}_{\mathrm{i}, \mathrm{t}}$} & $0.0264^{* * *}$ & $0.0230^{* *}$ & $0.0244 * *$ & $0.0234^{* *}$ \\
\hline & {$[0.0099]$} & {$[0.0093]$} & {$[0.0103]$} & {$[0.0100]$} \\
\hline $\mathrm{R}^{2}$ & 0.088 & 0.089 & 0.088 & 0.089 \\
\hline $\mathrm{N}$ & 5061 & 5079 & 5079 & 5061 \\
\hline
\end{tabular}

Notes: all computations made using StataSE 9.0.Constant not reported.

Robust standard errors in parentheses. Statistically significant at $* * * 1, * * 5, * 10$ percent level

Source: own estimation.

Due to the space constraints, the rest result considering different time periods and sector coverage are available from author upon request.

We are aware that the main problem in our specification (3) is due to the potential endogeneity between the growth rate and some of the independent variables. For example, higher growth rate of a given sector can be deterministic to the rise of trade activities. It is often assumed in literature that more productive firms are self-selected into export market (Wagner 2007), and in a similar manner productivity growth can stimulate imports (Djankov, Murrelli 2002). Additionally, we have to take into account the possibility of gender wage gap being influenced by the growth (not vice versa). However, as it is stated in the literature (World Bank 2011) it is highly difficult to find out a valid instruments for a gender wage gap. As the final robustness check, we use instrumental variables framework where the endogenous variables are instrumented by their lags. 
Table 6. The determinants of economic growth $\left(\Delta \mathrm{y}_{\mathrm{i}, \mathrm{t}}\right)-\mathrm{IV}$ estimation

\begin{tabular}{|c|c|c|c|c|c|c|c|c|}
\hline & (1) & (2) & (3) & (4) & (5) & (6) & (7) & (8) \\
\hline$\Delta \mathrm{l}_{\mathrm{ij}, \mathrm{t}}^{\mathrm{f}}$ & $0.092 * *$ & $0.094 * * *$ & $0.099 * * *$ & $0.101 * * *$ & $0.088 * * *$ & $0.095^{* * *}$ & $0.092 * * *$ & $0.097 * * *$ \\
\hline & {$[0.033]$} & {$[0.033]$} & {$[0.033]$} & {$[0.033]$} & {$[0.033]$} & {$[0.033]$} & {$[0.033]$} & {$[0.033]$} \\
\hline$\Delta \mathrm{l}_{\mathrm{ij}, \mathrm{t}}^{\mathrm{m}}$ & $0.269 * *$ & $0.268 * * *$ & $0.261 * * *$ & $0.261 * * *$ & $0.259 * * *$ & $0.251^{* * *}$ & $0.254 * * *$ & $0.251 * * *$ \\
\hline & {$[0.077]$} & {$[0.077]$} & {$[0.077]$} & {$[0.077]$} & {$[0.079]$} & {$[0.079]$} & {$[0.079]$} & {$[0.079]$} \\
\hline $\mathrm{W}^{\mathrm{HS}}{ }_{\mathrm{ij}, \mathrm{t}}$ & -0.017 & & & 0.001 & $-0.029 * *$ & & & -0.014 \\
\hline & {$[0.011]$} & & & [0.011] & {$[0.011]$} & & & {$[0.011]$} \\
\hline $\mathrm{W}^{\mathrm{MS}}{ }_{\mathrm{ij}, \mathrm{t}}$ & & $-0.055^{* *}$ & & $-0.045 * *$ & & $-0.064 * * *$ & & $-0.052 * * *$ \\
\hline & & {$[0.014]$} & & {$[0.015]$} & & {$[0.015]$} & & {$[0.016]$} \\
\hline $\mathrm{W}^{\mathrm{LS}}$ & & & $-0.049 * * *$ & $-0.036^{* * *}$ & & & $-0.034 * * *$ & $-0.018 *$ \\
\hline & & & {$[0.010]$} & {$[0.010]$} & & & {$[0.011]$} & {$[0.011]$} \\
\hline Trade $_{\mathrm{ij}, \mathrm{t}}$ & & & & & 0.012 & 0.014 & 0.01 & 0.015 \\
\hline & & & & & [0.009] & {$[0.009]$} & {$[0.008]$} & {$[0.009]$} \\
\hline $\mathrm{HC}_{\mathrm{ij}, \mathrm{t}}$ & & & & & $0.025 * * *$ & $0.023 * * *$ & $0.022 * * *$ & $0.021 * * *$ \\
\hline & & & & & {$[0.006]$} & {$[0.006]$} & {$[0.007]$} & {$[0.007]$} \\
\hline $\mathrm{R}^{2}$ & 0.104 & 0.106 & 0.105 & 0.107 & 0.106 & 0.106 & 0.105 & 0.107 \\
\hline $\mathrm{N}$ & 6752 & 6774 & 6774 & 6752 & 6437 & 6459 & 6459 & 6437 \\
\hline $\begin{array}{l}\text { Hansen } \\
\text { test } \\
\text { (p- } \\
\text { value) }\end{array}$ & 0.05 & 0.05 & 0.02 & 0.02 & 0.17 & 0.04 & 0.05 & 0.05 \\
\hline $\begin{array}{l}\text { F test } \\
(\mathrm{p}- \\
\text { value) }\end{array}$ & $0.092 * * *$ & $0.094 * * *$ & $0.099 * * *$ & $0.101 * * *$ & $0.088 * * *$ & $0.095^{* * *}$ & $0.092 * * *$ & $0.097 * * *$ \\
\hline
\end{tabular}

Notes: all computations made using XTIVREG2 for StataSE 9.0.Constant not reported. Robust standard errors in parentheses. Statistically significant at $* * * 1, * * 5, * 10$ percent level. Country/industry fixed effects and year dummies are included in all regressions. In all specifications the wage differentials and trade penetration instrumented by their first and second lags. Hansen's J statistics is the test of the model's overidentifying restrictions asymptotically $\chi 2 . \mathrm{F}$ - test is the test of excluded instruments in the first-stage regression. P-values reported.

Source: own estimation.

Table 6 presents the results of instrumental variables estimation. The wage differentials and trade penetration are instrumented by their first and second lags. We test whether the instruments are correlated with growth residuals using a Hansen test of the model's overidentifying restrictions. In most cases, we cannot reject the null hypothesis, so the instruments are valid in the sense that excluded exogenous variables are uncorrelated with the second stage residuals. Additionally, in each specification the instruments 
are highly statistically significant in the first-stage regression, and we can reject the hypothesis that the coefficients on the excluded exogenous variables are equal to zero in the first stage - see F test. In all specifications, the results consistently confirm a negative association between skill-specific gender wage gap and productivity growth. Still the trade openness is not statistically significant.

\section{Conclusions}

This paper has examined the impact of gender wage gap on productivity growth in 18 OECD countries at the sectoral level. The empirical study covers 12 manufacturing sectors between 1970 and 2005. We estimated an augmented production function where skill-specific gender wage gap constituted a potential determinant of growth. Neither theoretical framework nor previous empirical analysis give clear answer about the nature of the relationship between gender wage differentials and growth.

One of the main contributions of our study is to make estimates at sector level, compared to previous articles, which mostly make them at country or micro level. The utilization of three-dimensional panel data (sectors, countries, time) allows us to assess the disaggregated forces underlying productivity performance while accounting for unobserved heterogeneity. Additionally, a novelty of the present paper is the distinguishing between wages paid to different groups of workers classified according to skill level: high, medium and low.

The results indicate a negative relationship between gender wage gap and sectoral growth: other things being equal, higher the differences between female/male wages, slower the rate of productivity growth. Additionally, we confirmed the positive role of human capital on productivity growth, but we did not find a statistically significant coefficient on trade openness even if the later was instrumented. Our main conclusions are robust across numerous alternations of specification and variations, especially concerning the use of a different measure of human capital, the country composition in our analysis, industry heterogeneity and estimation techniques.

The results of our study have straightforward policy implications, especially considering promoting gender equality and providing antidiscrimination actions

Nevertheless, more research is needed to provide detail evidences on the importance of gender equality (both from the perspective of micro and macro level) for growth. 


\section{References}

Acemoglu D., Autor D., Lyle D. (2004), Women, War and Wages: The Effect of Female Labor Supply on the Wage Structure at Mid-Century, ,Journal of Political Economy", Vol. 112, No. 3, http://dx.doi.org/10.2139/ssrn.315522.

Barro R., Lee J-W. (2013), A New Data Set of Educational Attainment in the World 1950-2010, „Journal of Development Economics”, Vol. 104, http://dx.doi.org/10.1016/j.jdeveco.2012.10.001.

Becker G.S. (1971), The Economics of Discrimination, Chicago: University of Chicago Press.

Berik G., van der Meulen Rodgers Y., Seguino S. (2009), Feminist economics of inequality, development and growth, „Feminist Economics”, Vol. 15, No. 3, http://dx.doi.org/10.1080/13545700903093524.

Busse M., Spielmann Ch. (2006), Gender Inequality and Trade, „Review of International Economics", Vol. 14, No. 3, http://dx.doi.org/10.1111/j.14679396.2006.00589.x.

Caselli F. (2005), Accounting for Cross-Country Income Differences [in:] Aghion P, Durlauf S. (ed), Handbook of Economic Growth, Elsevier, Amsterdam.

Djankov S., Murrell P. (2002), Enterprise Restructuring in Transition: A Quantitative Survey, „Journal of Economic Literature”, Vol. XL, http://dx.doi.org/10.1257/002205102760273788.

Dominguez-Villalobos L., Brown-Grossman F. (2010), Trade Liberalization and Gender Wage Inequality in Mexico, ,Feminist Economics”, Vol. 16, No. 4, http://dx.doi.org/10.1080/13545701.2010.530582.

Field-Hendrey E. (1998), The Role of Gender in Biased Technical Change: U.S. Manufacturing, 1850-1919, „The Journal of Economic History”, Vol. 58, No. 4, http://dx.doi.org/10.1017/S0022050700021744.

Klasen S. (2002), Low schooling for girls, slower growth for all? Cross-country evidence on the effect of gender inequality in education on economic development. „World Bank Economic Review," Vol. 16, http://dx.doi.org/10.1093/wber/lhf004.

Klasen S., Lamanna F. (2009), The impact of gender inequality in education and employment on economic growth: New evidence for a panel of countries, „Feminist Economics", Vol. 15, No. 3, http://dx.doi.org/10.1080/13545700902893106.

Knowles S., Lorgelly P., Owen D. (2002), Are educational gender gaps a break on economic development?, „Oxford Economic Papers”, Vol. 54.

Oostendorp R.H. (2009), Globalization and the Gender Wage Gap, „World Bank Economic Review", Vol. 23, No. 1, http://dx.doi.org/10.1093/wber/lhn022.

Pervaiz Z., Irfan Ch.M., Ahmad J.S., Amatul R. (2011), Gender inequality and economic growth: a time series analysis for Pakistan, MPRA Paper 37176, University Library of Munich, Germany.

Schober, T., Winter-Ebmer R. (2011), Gender Wage Inequality and Economic Growth: Is There Really a Puzzle? - A Comment, „World Development”, Vol. 39, No. 8, http://dx.doi.org/10.1016/j.worlddev.2011.05.001.

Seguino, S. (2000), Gender inequality and economic growth: A cross-country Analysis, „World Development”, Vol. 28, No. 7, http://dx.doi.org/10.1016/S0305750X(00)00018-8. 
Seguino, S. (2011), Gender Inequality and Economic Growth: A Reply to Schober and Winter-Ebmer, ,World Development”, Vol. 39, No. 8.

Wagner J. (2007), Exports and Productivity: A Survey of the Evidence from Firmlevel Data, „The World Economy”, Vol. 30, No. 1, http://dx.doi.org/10.1111/j.1467-9701.2007.00872.x.

Weichselbaumer D., Winter-Ebmer R. (2005), A meta-analysis of the international gender wage gap, „Journal of Economic Surveys”, Vol. 19, No. 3, http://dx.doi.org/10.1111/j.0950-0804.2005.00256.x.

Wolszczak-Derlacz J. (2013), Mind the Gender Wage Gap - the Impact of Trade and Competition on Sectoral Wage Differences, ,The World Economy”, Vol. 36, No. 4, http://dx.doi.org/10.1111/twec.12026.

World Bank (2011), World Development Report 2012:. Gender Equality and Development, Washington DC.

\section{Appendix}

Table A1. List of sectors

\begin{tabular}{|l|l|}
\hline $\begin{array}{c}\text { Sector } \\
\text { (NACE) }\end{array}$ & \multicolumn{1}{c|}{ Description of sectors } \\
\hline $15 \mathrm{t} 16$ & C15T16 Food products, beverages and tobacco \\
\hline $17 \mathrm{t} 19$ & C17T19 Textiles, textile products, leather and footwear \\
\hline 20 & C20 Wood and products of wood and cork \\
\hline $21 \mathrm{t} 22$ & C21T22 Pulp, paper, paper products, printing and publishing \\
\hline 24 & C24 Chemicals and chemical products \\
\hline 25 & C25 Rubber and plastics products \\
\hline 26 & C26 Other non-metallic mineral products \\
\hline $27 \mathrm{t} 28$ & C27T28 Basic metals and fabricated metal products \\
\hline 29 & C29 Machinery and equipment, n.e.c. \\
\hline $30 \mathrm{t} 33$ & C30T33 Electrical and optical equipment \\
\hline $34 \mathrm{t} 35$ & C34T35 Transport equipment \\
\hline $36 \mathrm{t} 37$ & C36T37 Manufacturing n.e.c. and recycling \\
\hline 50 & $\begin{array}{l}\text { C50 Sale, maintenance and repair of motor vehicles and motorcycles - } \\
\text { retail sale of automotive fuel }\end{array}$ \\
\hline 51 & C51 Wholesale, trade and commission excl. motor vehicles \\
\hline 52 & C52 Retail trade excl. motor vehicles - repair of household goods \\
\hline
\end{tabular}


Table A1 continued

\begin{tabular}{|l|l|}
\hline \multicolumn{1}{|c|}{$\begin{array}{c}\text { Sector } \\
\text { (NACE) }\end{array}$} & \multicolumn{1}{c|}{ Description of sectors } \\
\hline $60 t 63$ & C60T63 Transport and storage \\
\hline 64 & C64 Post and telecommunications \\
\hline 70 & C70 Real estate activities \\
\hline 71 t74 & C71T74 Renting of mach. and equip. - other business activities \\
\hline AtB & C01T05 AGRICULTURE, HUNTING, FORESTRY AND FISHING \\
\hline C & C10T14 MINING AND QUARRYING \\
\hline D & C15T37 MANUFACTURING \\
\hline E & C40T41 ELECTRICITY GAS AND, WATER SUPPLY \\
\hline F & C45 CONSTRUCTION \\
\hline G & $\begin{array}{l}\text { C50T55 WHOLESALE AND RETAIL TRADE - RESTAURANTS } \\
\text { AND HOTELS }\end{array}$ \\
\hline H & C55 Hotels and restaurants \\
\hline I & C60T64 TRANSPORT, STORAGE AND COMMUNICATIONS \\
\hline J & C65T67 Financial intermediation \\
\hline K & C70T74 Real estate, renting and business activities \\
\hline L & C75 Public admin. and defence - compulsory social security \\
\hline M & C80 Education \\
\hline N & C85 Health and social work \\
\hline O & C90T93 Other community, social and personal services \\
\hline P & C95 Private households with employed persons \\
\hline TOT & CTOTAL TOTAL \\
\hline
\end{tabular}

Source: own calculations based on data from EU KLEMS 2008. 
Table A2. List of countries

\begin{tabular}{|l|l|l|}
\hline \multicolumn{1}{|c|}{ Lp. } & $\begin{array}{c}\text { Country } \\
\text { ISO }\end{array}$ & \multicolumn{1}{|c|}{ Country name } \\
\hline 1 & AUS & Australia \\
\hline 2 & AUT & Austria \\
\hline 3 & BEL & Belgium \\
\hline 4 & CZE & Czech Republic \\
\hline 5 & DNK & Denmark \\
\hline 6 & ESP & Spain \\
\hline 7 & FIN & Finland \\
\hline 8 & GER & Germany \\
\hline 9 & HUN & Hungary \\
\hline 10 & ITA & Italy \\
\hline 11 & JPN & Japan \\
\hline 12 & KOR & Korea \\
\hline 13 & NLD & Netherlands \\
\hline 14 & POL & Poland \\
\hline 15 & SVK & Slovak Republic \\
\hline 16 & SVN & Slovenia \\
\hline 17 & UK & United Kingdom \\
\hline 18 & USA & United States of America \\
\hline
\end{tabular}

Source: own elaboration.

Table A3. Fisher panel unit root test

\begin{tabular}{|c|c|c|c|c|}
\hline & \multicolumn{2}{|c|}{$\begin{array}{l}\text { Based on augmented Dickey- } \\
\text { Fuller tests }\end{array}$} & \multicolumn{2}{|c|}{ Based on Phillips-Perron tests } \\
\hline & $\begin{array}{l}\chi^{2}(\mathrm{p} \text {-value) } \\
\text { without trend }\end{array}$ & $\begin{array}{l}\chi 2(\mathrm{p} \text {-value }) \\
\text { with trend }\end{array}$ & $\begin{array}{l}\chi^{2}(\mathrm{p} \text {-value }) \\
\text { without trend }\end{array}$ & $\begin{array}{l}\chi^{2}(\mathrm{p} \text {-value }) \\
\text { with trend }\end{array}$ \\
\hline$\Delta y_{i j, t}$ & $3282.9(0.000)$ & $2848.6(0.000)$ & $6100.3(0.000)$ & $5273.5(0.000)$ \\
\hline$\Delta \mathrm{l}_{\mathrm{ijj}, \mathrm{t}}^{\mathrm{f}}$ & $1691.1(0.000)$ & $1571.5(0.000)$ & $2812.8(0.000)$ & $2611.8(0.000)$ \\
\hline$\Delta \mathrm{l}_{\mathrm{ij}, \mathrm{t}}^{\mathrm{m}, \mathrm{t}}$ & $1898.4(0.000)$ & $1657.2(0.000)$ & $2901.4(0.000)$ & $2585.7(0.000)$ \\
\hline$\Delta \mathrm{k}_{\mathrm{iji}, \mathrm{t}}$ & $857.4(0.000)$ & $1115.3(0.000)$ & $1166.3(0.000)$ & $1329.2(0.000)$ \\
\hline $\mathrm{W}^{\mathrm{His} \mathrm{i}}$ & $1549.8(0.000)$ & $1368.7(0000)$ & $1286.1(0.000)$ & $1068.1(0.000)$ \\
\hline $\mathrm{W}^{\mathrm{MS} \mathrm{S}_{\mathrm{ij}, \mathrm{t}}}$ & $586.5(0.000)$ & $611.1(0.000)$ & $686.5(0.000)$ & $600.1(0.000)$ \\
\hline $\mathrm{W}^{\mathrm{LS}} \mathrm{iji}_{\mathrm{ij}}$ & $360.4(0.056)$ & $426.5(0.045)$ & $969.5(0.000)$ & $964.4(0.000)$ \\
\hline Trade $_{\mathrm{ij}, \mathrm{t}}$ & $904.3(0.000)$ & $713.2(0.000)$ & $3229.4(0000)$ & $3101.5(0.000)$ \\
\hline $\mathrm{HC}_{\mathrm{i}, \mathrm{t}, \mathrm{i}}$ & $555.7(0.001)$ & $877.2(0.000)$ & $519.8(0.002)$ & $939.8(0.000)$ \\
\hline
\end{tabular}

Source: own elaboration. 